\title{
The macroanatomy of the brachial plexus and its nerves in the common buzzard (Buteo buteo)
}

\author{
Yalcin Akbulut ${ }^{1 *}$, Ramazan Ilgun², Bestami Yilmaz ${ }^{3}$, Kadir Aslan', \\ and Erdogan Uzlu ${ }^{4}$
}

\author{
${ }^{1}$ Department of Anatomy, Faculty of Veterinary Medicine, Kafkas University, Kars, Turkey \\ ${ }^{2}$ Department of Anatomy, Faculty of Veterinary Medicine, Aksaray University, Aksaray, Turkey \\ ${ }^{3}$ Department of Anatomy, Faculty of Veterinary Medicine, Harran University, Sanliurfa, Turkey \\ ${ }^{4}$ Wildlife Rescue and Rehabilitation Center of Kafkas University, Kars, Turkey
}

\begin{abstract}
AKBULUT, Y., R. ILGUN, B. YILMAZ, K.ASLAN, E. UZLU: The macroanatomy of the brachial plexus and its nerves in the common buzzard (Buteo buteo). Vet. arhiv 87, 759-768, 2017.
\end{abstract}

\section{ABSTRACT}

The purpose of this study was to elucidate the anatomical structure of the brachial plexus in the common buzzard (Buteo buteo). Five common buzzards (two females and three males) provided by the Wildlife Rescue and Rehabilitation Centre of Kafkas University were used. The nerves of the brachial plexus and the accessory brachial plexus were dissected and photographed. Two plexuses were found the brachial plexus and the accessory brachial plexus. It was also found that the v. jugularis, the a. carotis communis and the $\mathrm{n}$. vagus were located medially of the brachial plexus, while the v. subclavia and the a. subclavia were located in the caudal part of the plexus. In addition, it was observed that the accessory brachial plexus was located in the cranial region, and that it originated from a merger of the ventral branches of cervical spinal nerve 10 and 11 (C10 and C11). The mean diameters of $\mathrm{C} 10$ and $\mathrm{C} 11$ were measured as $0.49 \pm 0.07$ and $0.69 \pm 0.10 \mathrm{~mm}$, respectively. It was found that the brachial plexus originated from a merger of the ventral branches of the last three cervical spinal nerves $(\mathrm{C} 11$, $\mathrm{C} 12$, and $\mathrm{C} 13$ ) with the ventral branches of the first two thoracic (T1 and T2) spinal nerves. There was no gender difference in terms of the formation of the brachial plexus and the accessory brachial plexus. The diameters of these branches, which joined at the point of origin of the brachial plexus, were measured as $0.69 \pm 0.10$ (C11), $1.27 \pm 0.04$ (C12), $2.13 \pm 0.11(\mathrm{C} 13), 1.81 \pm 0.14$ (T1) and $0.98 \pm 0.14 \mathrm{~mm}(\mathrm{~T} 2)$. Thus, the formation of the brachial plexus in the common buzzard, the spinal nerves that formed the plexus, and the innervation areas of these nerves were observed and presented.

Key words: neuroanatomy, avian, brachial plexus, common buzzard

\footnotetext{
${ }^{*}$ Corresponding author:

Yalcin Akbulut, Department of Anatomy, Faculty of Veterinary Medicine, Kafkas University, Kars, 36100, Turkey, Phone: + 90 474242 6807, E-mail: yalcinakbulut@kafkas.edu.tr
} 
Y. Akbulut et al.: The macroanatomy of the brachial plexus and its nerves in the common buzzard (Buteo buteo)

\section{Introduction}

The common buzzard (Buteo buteo) is a medium to large bird of prey, whose range covers most of Europe and extends into Asia. The B. buteo populations in Britain, Southern Europe, Turkey, The Caucasus, Japan, and the smaller islands are resident throughout the year. The feather colours of the common buzzard are observed to have different tones, ranging from brown to black. Its total length is generally $51-57 \mathrm{~cm}$, and the length of the tail and tarsus is 193-236 mm and 69-83 mm, respectively (DEL HOYO et al., 1994; FERGUSON-LEES and CHRISTIE, 2001).

The nerves of the wing and trunk arise from the brachial plexus, which is a network of nerves formed by the ventral roots of the last two cervical spinal nerves and the first two or three thoracic spinal nerves in the fowl. In the domestic fowl, nerves 13 to 16 , and sometimes also 17, arise from the brachial plexus (NICKEL et al., 1977; KING and McLELLAND, 1984; DURSUN, 2002). In the raptor Merlin, the brachial plexus is formed from a merger of the ventral branches of the last three cervical nerves and the first two thoracic nerves (CEVIK-DEMIRKAN, 2013). Thenerves that form the brachial plexus are the $\mathrm{n}$. sternocoracoideus, $\mathrm{n}$. supracoracoideus, $\mathrm{n}$. subcoracoscapularis, $\mathrm{n}$. m. scapulohumeralis dorsalis, n. m. coracobrachialis caudalis, n. axillaris, n. m. coracobrachialis cranialis, $n$. latissimus dorsi, n. pectoralis, $n$. anconeus, n. medianoulnaris, n. ulnaris, and n. radialis (BAUMEL et al., 1993). In many birds, an accessory brachial plexus is also present. This is a network of small nerves that arise from two to four of the more cranial roots of the main plexus. The $\mathrm{n}$. m. rhomboideus, $\mathrm{n}$. cutaneus omalis and $\mathrm{n}$. $\mathrm{m}$. serratus arise from the accessory brachial plexus in Merlin (HOWELL, 1937; CEVIK-DEMIRKAN, 2013).

Although numerous studies have been conducted on the anatomy of the brachial plexus in different poultry species, such as: the great horned owl (MOORE et al., 1989), the red tailed hawk (SHELL et al., 1993), the turkey (MOREIRA et al., 2005), cockatiel (MURPHY and SHIVAPRASAD 2008), chicken (CARDOZA et al., 2009), the mallard duck (BRENNER et al., 2010), the Merlin (CEVIK-DEMIRKAN, 2013) and the macaw (FILHO et al., 2014), no study has been conducted so far on the brachial plexus in the common buzzard. For this reason, the aim of this study was to elucidate the macroanatomical properties of the brachial plexus in the common buzzard and to compare the properties with those of other avian species.

\section{Materials and methods}

This study was carried out with the permission of the General Directorate of Nature Conservation and National Parks, Ministry of Forestry and Water Affairs, in June 2015. A total of five adult buzzards (three male and two female) donated by the Wildlife Rescue and Rehabilitation Center of Kafkas University were used in this study. First, the thoracic cavities of the animals were opened. The birds were immersed in $10 \%$ formalin solution, 
where they remained for 2 weeks for fixation. Both sides of the samples were used in the study. The measurements were made with digital calipers (0.01, BTS-UK). The diameters of the nerves are summarized in Table 1. Finally, the brachial plexus and the nerve branches emerging from it were carefully dissected and photographed with a Kodak M 320. The Nomina Anatomica Avium was referred to for nomenclature (BREAZILE and YASUDA, 1979; BAUMEL et al., 1993).

Table 1. Summary of the nerve branch diameters

\begin{tabular}{|l|c|c|}
\hline \multirow{2}{*}{ Nerves } & \multicolumn{2}{|c|}{ Diameter of nerves } \\
\cline { 2 - 3 } & Mean $(\mathrm{mm})$ & $\pm \mathrm{SD}$ \\
\hline C10 11 & 0.49 & 0.07 \\
\hline C12 & 0.69 & 0.10 \\
\hline C13 & 1.27 & 0.04 \\
\hline T1 & 2.13 & 0.11 \\
\hline T2 & 1.81 & 0.14 \\
\hline N. radialis & 0.98 & 0.14 \\
\hline N. medianoulnaris & 1.56 & 0.35 \\
\hline N. ulnaris & 1.53 & 0.25 \\
\hline N. medianus & 0.58 & 0.10 \\
\hline N. pectoralis & 0.67 & 0.07 \\
\hline Cranial root of n.pectoralis & 1.52 & 0.10 \\
\hline Caudal root of n.pectoralis & 1.11 & 0.12 \\
\hline
\end{tabular}

\section{Results}

We found that the common buzzard has two plexuses: the brachial plexus and the accessory brachial plexus. It was observed that the v. jugularis, a. carotis communis and $\mathrm{n}$. vagus were located in the medial part of the plexuses. It was also found that the $\mathrm{v}$. subclavia and a. subclavia were located in the caudal part of the plexuses in the common buzzard (Fig. 1). In addition, an accessory brachial plexus was found in the cranial region; it was formed by a merger of the ventral branches of cervical spinal nerves 10 and 11 (C10 and C11) (Fig. 2). The mean diameters of $\mathrm{C} 10$ and $\mathrm{C} 11$ were $0.49 \pm 0.07$ and 0.69 $\pm 0.10 \mathrm{~mm}$, respectively. It was specifically noted that $\mathrm{C} 10$ proceeded, in the case of a sole root, and dispersed in the m. rhomboideus superficialis. Further, it was established that $\mathrm{C} 11$ diverged into the cranial and caudal roots, and that the caudal branch joined the brachial plexus (Fig. 2). Later, it was confirmed that the cranial root diverged into three thin branches, and that these thin branches dispersed in the $\mathrm{m}$. rhomboideus profundus and the $\mathrm{m}$. serratus profundus. 
Y. Akbulut et al.: The macroanatomy of the brachial plexus and its nerves in the common buzzard (Buteo buteo)

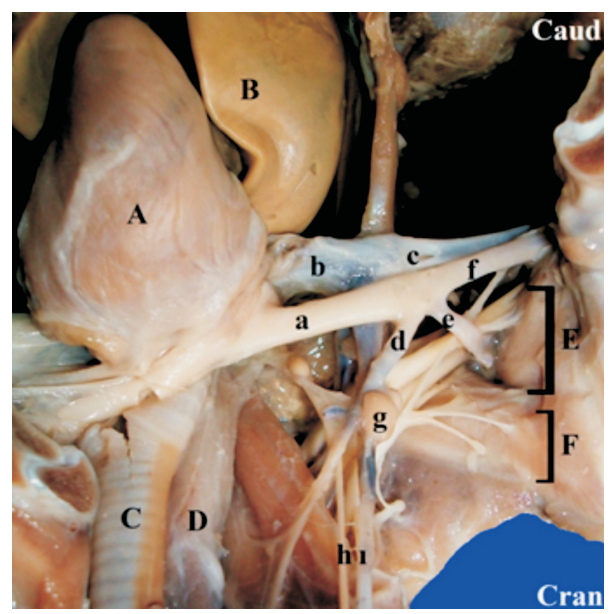

Fig. 1. The brachial plexus and neighborhoods (ventral view). A) heart, B) lobus hepatis dexter, C) trachea, D) oesophagus, E) brachial plexus, F) accessory brachial plexus, a) a. brachiocephalica dexter, b) v. cava cranialis dexter, c) v. subclavia dexter, d) a. carotis communis dexter, e) a. axillaris, f) a. subclavia dexter, g) thyroid gland, h) n. vagus, 1) v. jugularis dexter

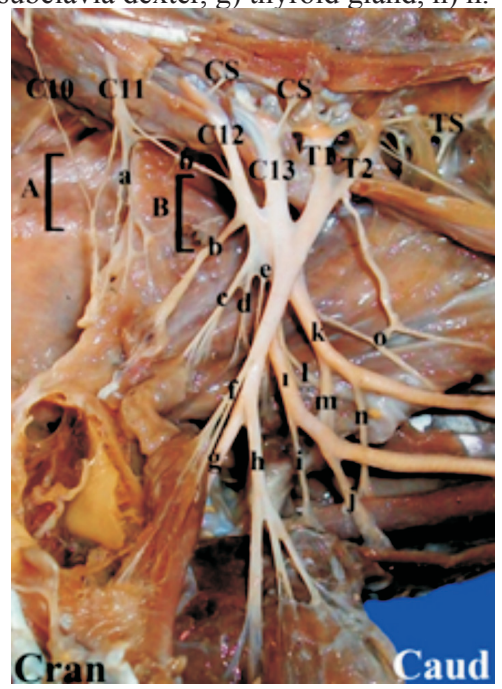

Fig. 2. The accessory brachial plexus and brachial plexus (ventral view). A) accessory brachial plexus, B) brachial plexus, a) n. cutaneus omalis, b) n. m. sternocoracoideus, c) n. supracoracoideus, d) n. subcoracoscapularis, e) n. m. scapulohumeralis dorsalis, f) n. m. coracobrachialis caudalis, g) n. pectoralis cranialis, h) n. pectoralis caudalis, 1) n. medianoulnaris, i) n. cutaneous ventralis brachialis, j) n. bicipitalis, k) n. radialis, l) n. m. latissimus dorsi, m) n. axillaris, n) n. m. tricipitis, o) n. anconealis 
Y. Akbulut et al.: The macroanatomy of the brachial plexus and its nerves in the common buzzard (Buteo buteo)

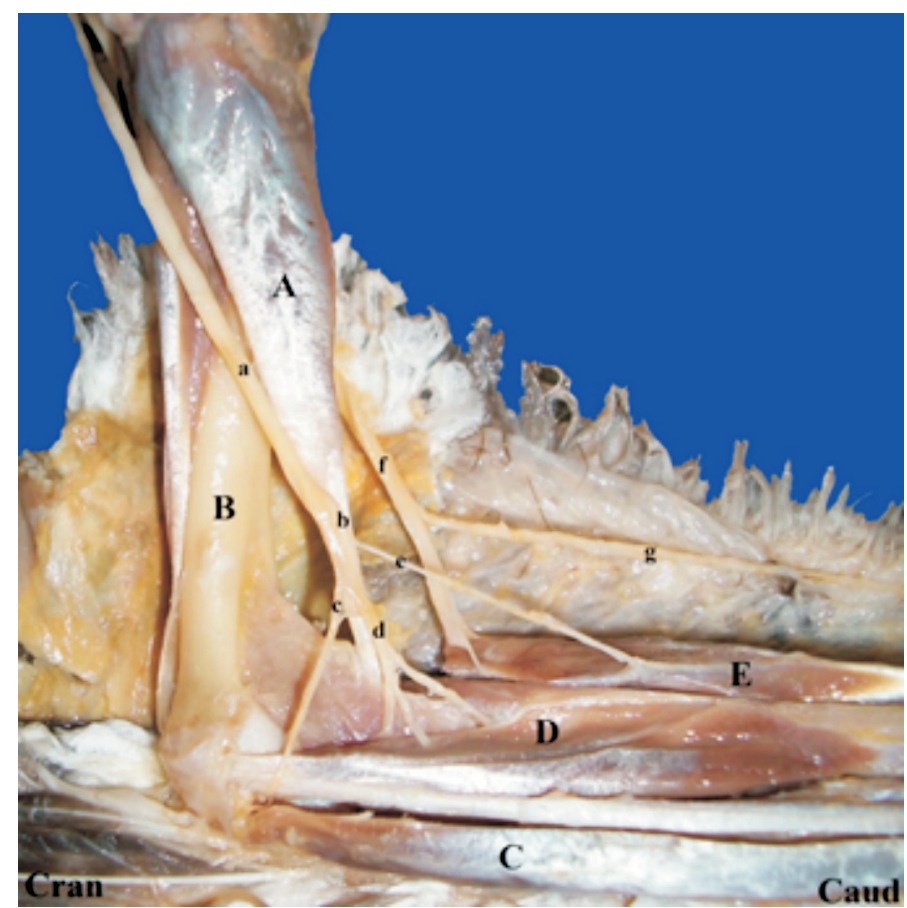

Fig. 3. The branches of $n$. medianoulnaris and n. radialis (ventral view). n. medianoulnaris, b) medianus, c) n. ulnaris, d) the deep ramus of $n$. medianus, e) the superficial ramus of n. medianus, f) n. radialis, g) the mutual root the $n$. propatagialis dorsalis and the n. cutaneous antebrachialis dorsalis, A) m. biceps brachii, B) humerus, C) m. flexor carpi ulnaris, D) m. pronator longus et brevis, E) $\mathrm{m}$. extensor carpi radialis

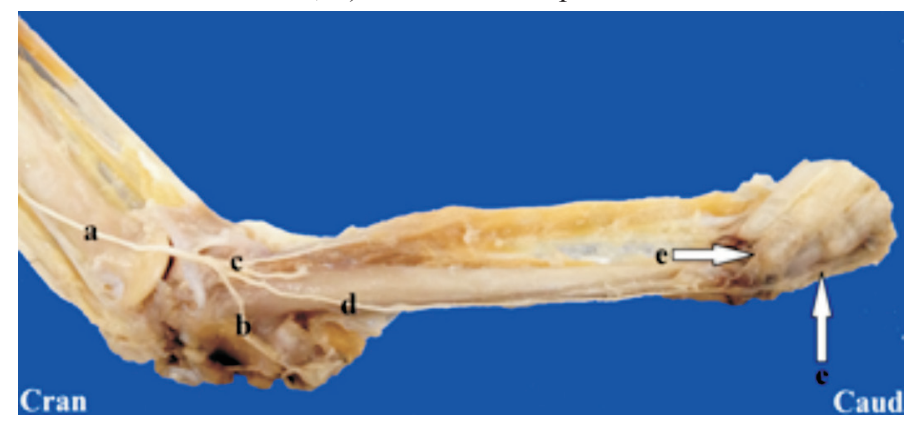

Fig. 4. The last branches of $n$. radialis (dorsal view). a) The deep ramus of $n$. radialis, b) r. alularis, c) rr. postpatagialis, d) nn. metacarpales dorsales, e) rr. digitales 
The brachial plexus was derived from a merger of the ventral branches of the last three cervical spinal nerves $(\mathrm{C} 11, \mathrm{C} 12, \mathrm{C} 13)$ and the ventral branches of the first two thoracic spinal nerves (T1 and T2) (Fig. 2). No difference was found between the male and female common buzzard in terms of the formation of the brachial plexus and the accessory brachial plexus. The diameters of these branches that joined the brachial plexus were measured as $0.69 \pm 0.10(\mathrm{C} 11), 1.27 \pm 0.04(\mathrm{C} 12), 2.13 \pm 0.11(\mathrm{C} 13), 1.81$ \pm 0.14 (T1) and $0.98 \pm 0.14 \mathrm{~mm}$ (T2), respectively (Table 1). It was observed that the brachial plexus consisted of two fasciculi-the fasciculus dorsalis and the fasciculus ventralis. It was also found that the dorsal fasciculi originated from $\mathrm{C} 11, \mathrm{C} 12$ and $\mathrm{C} 13$, and that the ventral fasciculi was comprised of T1 and T2 (Fig. 2). It was found that the n. subcoracoscapularis, n. m. scapulohumeralis dorsalis, n. m. latissimus dorsi, $n$. axillaris, $n$. deltoideus, $n$. cutaneous brachialis dorsalis and $n$. radialis originated from the fasciculus dorsalis (Fig. 2). The n. subcoracoscapularis and n. m. scapulohumeralis dorsalis divided into $\mathrm{C} 12$ and $\mathrm{C} 13$, and the $\mathrm{m}$. subscapularis and $\mathrm{m}$. scapulohumeralis dispersed in the cranialis. It was observed that the n. m. latissimus dorsi originated from the ventral branches of $\mathrm{C} 12$ and $\mathrm{C} 13$ and innervated the m. latissimus dorsi. Moreover, the n. cutaneous brachialis dorsalis innervated the skin through the middle of the forearm. It was observed that the $\mathrm{n}$. axillaris and $\mathrm{n}$. deltoideus were formed from the ventral branches of $\mathrm{C} 12$ and $\mathrm{C} 13$ and innervated the muscle and skin of the shoulder area.

We observed that the diameter of the $n$. radialis consisted of ventral branches of $\mathrm{C} 12$ and $\mathrm{C} 13$, and was an average of $1.56 \pm 0.35 \mathrm{~mm}$ (Table 1). It was found that the $\mathrm{n}$. radialis innervated the $\mathrm{m}$. triceps brachii, $\mathrm{m}$. extensor carpi ulnaris, $\mathrm{m}$. extensor carpi radialis and $\mathrm{m}$. extensor digitorum communis via its processes. Moreover, the n. radialis divided into two superficial branches and several deep branches at one-third of the elbow (Fig. 3). The superficial branches dispersed in the m. extensor digitorum communis, while the deep branches innervated the $\mathrm{m}$. adductor alulae, $\mathrm{m}$. interosseus dorsalis and $\mathrm{m}$. ulnometacarpalis dorsalis, and terminated in the rr. digitales (Fig. 4).

It was established that the $\mathrm{n}$. $\mathrm{m}$. sternocoracoideus, $\mathrm{n}$. supracoracoideus, $\mathrm{n}$. pectoralis, $\mathrm{n}$. medioulnaris and $\mathrm{n}$. cutaneous brachialis ventralis originated from the fasciculus ventralis (Fig. 2). The n. m. sternocoracoideus was segregated from C11, and it dispersed in the $\mathrm{m}$. sternocoracoideus. It was observed that the $\mathrm{n}$. supracoracoideus was segregated from $\mathrm{C} 11$ and $\mathrm{C} 12$, and that it dispersed in the $\mathrm{m}$. supracoracoideus (Fig. 2).

The mean diameter of the $\mathrm{n}$. medianoulnaris originated from the ventral branches of $\mathrm{C} 13, \mathrm{~T} 1$ and $\mathrm{T} 2$, and it was $1.53 \pm 0.25 \mathrm{~mm}$ (Table 1). It was then found that the $\mathrm{n}$. medianoulnaris innervated the m. biceps brachii and the m. coracobrachialis (Fig. 3). The $\mathrm{n}$. cutaneous brachialis ventralis originated from the lateral $\mathrm{n}$. medianoulnaris and dispersed in the ventral area of the arm. It was found that the n. medianoulnaris segregated into the $\mathrm{n}$. ulnaris, which was $0.58 \pm 0.10 \mathrm{~mm}$ in diameter and an average distance of 7.6 
$\mathrm{cm}$ from the elbow joint where it had originated, and $\mathrm{n}$. medianus, which was $0.67 \pm 0.07$ $\mathrm{mm}$ in diameter (Fig. 3). It was confirmed that the n. ulnaris innervated the $\mathrm{m}$. flexor carpi ulnaris and $\mathrm{m}$. flexor digitorum superficialis, while the $\mathrm{n}$. medianus innervated the $\mathrm{m}$. flexor carpi radialis, $\mathrm{m}$. flexor digitorum superficialis and $\mathrm{m}$. flexor digitorum profundus.

It was also found that the $\mathrm{n}$. pectoralis was derived from the ventral branches of $\mathrm{C} 13$, $\mathrm{T} 1$ and $\mathrm{T} 2$, and that its diameter was $1.52 \pm 0.10 \mathrm{~mm}$ (Fig. 2). The n. pectoralis segregated into two branches the cranial branch, which was $1.11 \pm 0.12 \mathrm{~mm}$ in diameter, and the caudal branch, which was $0.90 \pm 0.18 \mathrm{~mm}$ in diameter and innervated the $\mathrm{m}$. pectoralis.

\section{Discussion}

In this study, it was found that the brachial plexus of the common buzzard consisted of a total of five ventral branches of spinal nerves ( $\left(11^{\text {th }}\right.$ to $\left.15^{\text {th }}\right)$. It has been reported that the brachial plexus comprises five roots in the Merlin (CEVIK-DEMIRKAN, 2013), common swift and swans (KING and McLELLAND, 1984), while it originates from four spinal nerves in the cardinal, the white-throated sparrow, the song sparrow $\left(11^{\text {th }}\right.$ to $\left.14^{\text {th }}\right)$ (SWINEBROAD, 1954), duck and goose (17 th to $20^{\text {th }}$ ) (FÜRBRINGER, 1902). Further, the brachial plexus comprises three spinal nerves in the English sparrow $\left(11^{\text {th }}\right.$ to $\left.13^{\text {th }}\right)$ and the Northern ground hornbill $\left(13^{\text {th }}\right.$ to $\left.15^{\text {th }}\right)$, although it is comprised of the last cervical medulla spinalis and the first thoracic segment in the ostrich (POSPIESZNY et al., 2009).

The accessory brachial plexus is located in front of the brachial plexus in the Merlin (CEVIK-DEMIRKAN, 2013), but this plexus is not present in the ostrich (POSPIESZNY et al., 2009). This study found that the accessory brachial plexus was derived from the ventral branches of the $10^{\text {th }}$ and $11^{\text {th }}$ cervical spinal nerves, and was present in front of the brachial plexus in the common buzzard.

In this study, the last spinal nerve (C13) was found to be the thickest nerve, with a diameter of $2.13 \pm 0.11 \mathrm{~mm}$, and it joined the brachial plexus of the ventral branch. YILDIZ and BAHADIR (1999) reported that in the chicken and duck, the $15^{\text {th }}$ cervical spinal nerve was the thickest, with a diameter of $1.32 \mathrm{~mm}$ and $1.43 \mathrm{~mm}$ respectively, and in the pigeon, the $13^{\text {th }}$ ventral branch of the cervical spinal nerve was the thickest, with a diameter of $1.27 \pm 0.04 \mathrm{~mm}$.

YILDIZ and BAHADIR (1999) also reported that the n. pectoralis cranialis is thicker than the $\mathrm{n}$. pectoralis caudalis in the chicken, and that the $\mathrm{n}$. pectoralis caudalis is thicker than the $\mathrm{n}$. pectoralis cranialis in the duck; however, in the pigeon, the diameter of these two branches is similar. Our research revealed that the $\mathrm{n}$. pectoralis cranialis had a greater diameter than the $\mathrm{n}$. pectoralis caudalis in the common buzzard.

CEVIK-DEMIRKAN (2013) explained that the $n$. medianoulnaris originates from the ventral branches of $\mathrm{C} 13, \mathrm{~T} 1$ and $\mathrm{T} 2$, and divides into the $\mathrm{n}$. ulnaris and $\mathrm{n}$. medianus, of which the $\mathrm{n}$. medianus is thicker in the Merlin. In this regard, this study revealed that 
the $n$. medianoulnaris originated from the ventral branches of the same spinal nerves. Additionally, the diameters of the $\mathrm{n}$. medianus and $\mathrm{n}$. ulnaris were found to be $0.67 \pm 0.07$ and $0.58 \pm 0.10 \mathrm{~mm}$, respectively.

According to HOWELL'S findings (1937), all branches of the brachial plexus of domestic birds joined the n. radialis; however, NICKEL et al. (1977) argued that the $\mathrm{n}$. radialis originated from the $\mathrm{nn}$. brachiales dorsales. This study revealed that in the common buzzard, the $\mathrm{n}$. radialis was formed from the ventral branches of $\mathrm{C} 12$ and $\mathrm{C} 13$ and that it progressively innervated the $\mathrm{m}$. extensor digitorum communis, $\mathrm{m}$. adductor alulae, $\mathrm{m}$. interosseus dorsalis and $\mathrm{m}$. ulnometacarpalis dorsalis.

This study revealed that the $\mathrm{n}$. bicipitalis originated from the $\mathrm{n}$. medianoulnaris and then innervated the m. biceps brachii, and that the n. m. tricipitis originated from the $n$. radialis and innervated the $\mathrm{m}$. triceps brachii. These findings are in agreement with those of BAUMEL et al., (1993), KING and McLELLAND (1984), and YILDIZ and BAHADIR (1999). MOORE et al. (1989) suggested that brachial plexus avulsion, neurologic dysfunction, and nerve conduction velocity could be detected using electromyography, and that knowledge about the diameter of the nerves, their progression, and the area of innervation may be useful in disease diagnosis in these species.

In conclusion, the macroanatomy of the brachial plexus and its branches in the common buzzard has been reported. Moreover, the anatomical structure of the brachial plexus in the common buzzard was compared to that of other avian species. It is believed that all these findings can contribute to electrodiagnostic evaluations in the common buzzard, especially in cases of surgical operations at wildlife protection centers.

\section{Acknowledgements}

We thank for their support to the Wildlife Rescue and Rehabilitation Center of Kafkas University, Assist. Prof. Ekin Emre ERKILIC and Dr. Burak BUYUKBAKI for their valuable contributions to the manuscript.

\section{References}

BAUMEL, J. J., A. S. KING, J. E. BREAZILE, H. E. EVANS, J. C. VANDEN BERGE (1993): Handbook of avian anatomy: nomina anatomica avium. Nuttall Ornithological Club, Massachusetts, 570-580.

BREAZILE, J. E., M. YASUDA (1979): Systema nervosum peripheriale. In: Nomina anatomica avium. (Baumel, J. J., A. S. King, A. M. Lucas, J. E. Breazile, H. E. Evans, Eds.). Academic Press, London and New York. 473-503.

BRENNER, D. J., R. S. LARSEN, P. J. DICKINSON, R. F. WACK, D. C. WILLIAMS, P. J. PASCOE (2010): Development of an avian brachial plexus nerve block technique for perioperative analgesia in mallard ducks (Anas platyrhynchos). J. Avian Med. Surg. 24, 24-34. 
Y. Akbulut et al.: The macroanatomy of the brachial plexus and its nerves in the common buzzard (Buteo buteo)

CARDOZA, L. B., R. M. ALMEIDA, L. C. FIUZA, P. D. GALERA (2009): Brachial plexus blockade in chickens with $0.75 \%$ ropivacaine. Vet. Anaesth. Analg. 36, 396-400.

CEVIK-DEMIRKAN, A. (2013): Anatomical structure of the Brachial plexus in the Merlin (Falco columbarius). Anat. Histol. Embryol. 43, 31-35.

DEL HOYO, J., A. ELLIOTT, J. SARGATAL (1994): Handbook of the birds of the world. New World Vultures to Guineafowl. Lynx Edicions, Barcelona, 638.

DURSUN, N. (2002): The Anatomy of Domestic Birds. Medisan, Ankara, 232.

FERGUSON-LEES, J., D. A. CHRISTIE (2001): Raptors of the world: An identification guide to the birds of prey of the world. Houghton Mifflin, New York, 992.

FILHO, K. A., M. N. RODRIGUES, E. T. FONSECA, R. M. LEANDRO, V. B. PASQUALETTI, M. A. MIGLINO (2014): Origin, distribution, and insertion of the brachial plexus nerves in blue-and-yellow macaws (Ara ararauna, Linnaeus, 1758). Revista Biotemas 27, 157-166.

FÜRBRINGER, M. (1902): Zur vergleichenden Anatomie des Brustschulterapparates und der Schultermuskeln. Von Max Fürbringer. Jena, Gustav Fischer, 736.

HOWELL, A. B. (1937): Morphogenesis of the shoulder architecture. Aves Auk 54, 364-374.

KING, A. S., J. McLELLAND (1984): Birds: Their structure and function. Bailliere Tindall, Printed in Great Britian at The Pitman Press, London, 342.

MOORE, M. P., E. STAUBER, N. THOMAS (1989): Avulsion of the brachial plexus in a great horned owl (Bubo virginianus). J. Raptor. Res. 23, 3-9.

MOREIRA, P. R. R., W. M. SOUZA, N. T. M. SOUZA, R. G. CARVALHO, A. A. CUSTODIO (2005): The arragement of configurat of nerves of brachial plexus in the turkey (Meleagris gallopavo - Linnaeus, 1758). Ars. Veterinaria, Jaboticabal 21, 296-302.

MURPHY, B. G., H. L. SHIVAPRASAD (2008): Ganglioneuroma of the brachial plexus in two cockatiels (Nymphicus hollandicus). Vet. Pathol. 45, 690-692.

NICKEL, R., A. SCHUMMER, E. SEIFERLE (1977): Anatomy of the domestic birds. Verlag Paul Parey, Berlin-Hamburg,131-139.

POSPIESZNY, N., P. PACHULSKA, K. PAZDZIOR, J. WUSTINGER (2009): Nerves of thoracic limb of the ostrich (Struthio camelus L.). J. Polish. Agri. Univ. 12, 1-5.

SHELL, L., M. RICHARDS, G. SAUNDERS (1993): Brachial plexus injury in two red-tailed hawks (Buteo jamaicensis). J. Wildl. Dis. 29, 177-179.

SWINEBROAD, J. (1954): A comparative study of the wing myology of certain passerines. Am. Midl. Nat. 51, 488-514.

YILDIZ, H., A. BAHADIR (1999): A macroanatomic and subgross examination of ventral cord originating from brachial plexus, till the region of wrist in the chickens, domestic cucks and pigeons. Vet. Bil. Derg. 15, 129-138.

Received: 30 September 2016

Accepted: 19 March 2017

Vet. arhiv 87 (6), 759-768, 2017 


\section{AKBULUT, Y., R. ILGUN, B. YILMAZ, K. ASLAN, E. UZLU: Makroanatomija brahijalnog spleta i njegovi živci u škanjca (Buteo buteo). Vet. arhiv 87, 759-768, 2017.}

\section{SAŽETAK}

Svrha ovog rada bila je rasvijetliti anatomsku građu brahijalnog spleta u škanjca (Buteo buteo). Istraživanje je provedeno na pet škanjaca (dvije ženke i tri mužjaka) podrijetlom iz Centra za spašavanje i oporavak divljači Sveučilišta u Kavkazu. Secirani su i fotografirani živci brahijalnog spleta i akcesornog brahijalnog spleta. Ustanovljeno je da su v. jugularis, a. carotis communis i n. vagus bili smješteni medijalno od brahijalnog spleta, dok su v. subclavia i a. subclavia bile smještene u kaudalnom dijelu spleta. Povrh toga ustanovljeno je da je akcesorni brahijalni splet bio smješten u kranijalnom području te da je nastao spajanjem ventralnih grana 10 . i 11. vratnog kralježničnog živca (C10 i C11). Srednja vrijednost promjera C10 iznosila je $0,49 \pm 0,07$, a C11 $0,69 \pm 0,10 \mathrm{~mm}$. Ustanovljeno je da je brahijalni splet potjecao od ventralnih grana posljednjih triju vratnih kralježničnih živaca (C11, C12 i C13) i ventralnih grana prvih dvaju grudnih kralježničnih živaca (T1 i T2). Nije ustanovljena razlika s obzirom na spol. Promjer istraživanih grana, koje su spojene na izlazištu brahijalnog

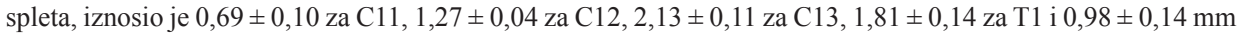
za T2. Time je prikazan nastanak brahijalnog spleta u škanjca, kralježničnih živaca koji ga oblikuju i njihovo inervacijsko područje.

Ključne riječi: neuroanatomija, ptice, brahijalni splet, škanjac 